\title{
Perancangan Sistem Informasi Pembelajaran Berbasis Web
}

\author{
Yoyok Sabar, Risna Sari, Euis Oktavianti \\ Program Studi Teknik Informatika \\ Jurus an Teknik Informatika dan Komputer \\ Politeknik Negeri Jakarta \\ yoyok.sw@tik.pni.ac.id, risna.sari@tik.pnj.ac.id, euis.oktavianti@tik.pni.ac.id
}

Diterima: 5 Agustus 2017. Disetujui: 3 September 2017. Dipublikasikan: November 2017

\begin{abstract}
Abstrak - Sistem Informasi Pendidikan Politeknik yang diperikan berupa tersedianya basis data yang dapat diakses dan digunakan untuk keberlangsungan proses belajar mengajar di JTIK khususnya pada Program Studi Teknik Informatika. Perancangan Sistem Informasi Pendidikan TIK menggunakan metodologi Lean Business Model Design karena fungsi-fungsi yang terdapat di sistem tidak terlalu komplek serta waktu pengerjaan yang lebih singkat dikarenakan protype akan berhenti jika semua fungsi sudah sesuai dengan keinginan pengguna. Hasil penelitian diharapkan berkontribusi dalam memberikan layanan lebih baik dan sebagai sumber referensi dalam pemenuhan borang akreditas institusi, sehingga tercapai visi program studi Teknik Informatika dalam hal ini menjadikan program studi Teknik Informatika yang unggul berkelas dunia pada tahun 2029 dan salah satu misinya menyelenggarakan pendidikan dan pelayanan yang berbasis teknologi informasi.
\end{abstract}

Kata Kunci: metodologi lean, model design, perancangan perangkat lunak.

\section{PENDAHULUAN}

Politeknik Negeri Jakarta merupakan salah satu lembaga pendidikan tinggi yang memberikan layanan proses pembelajaran untuk meluluskan sumber daya manusia cerdas dan berkarakter. Pendidikan tinggi memiliki kriteria lebih tinggi dibanding dengan pendidikan umum, atau tingkat pendidikan dibawahnya. Ini mengaitkan perbandingan tidak hanya pada tingkat ilmu pengetahuan dan teknologi saja, namun pada proses layanan yang diberikan pun harusnya lebih baik. Kebaikan layanan dipandang memiliki korelasi kuat terhadap hasil, berupa sumber daya manusia yang cerdas dan berkarakter. Su mber daya manusia cerdas dan berkarakter baik men jadi tolok u kur atas layanan proses pembelajaran yang dilaksanakan.

Proses pembelajaran merupakan interaksi yang saling berhubungan antara pemberi dan penerima informasi, untuk hal ini tenaga pendidik dan kependidikan sebagai pemberi informasi dan mahasiswa sebagai penerima informasi. Tenaga pendidik memberikan informasi mengenai sumber ilmu pengetahuan dan teknologi, sementara tenaga kependidikan memberikan informasi tentang layanan administrasi tentang proses pembelajaran. Sedangkan mahasiswa sebagai penerima informasi, yang sekaligus dikatakan sebagai penerima layanan, akan mendapatkan informasi serta layanan yang diberikan tenaga pendidik dan kependidikan.

Tujuan penelitian ini adalah merancang sistem informasi pendidikan dalam rangka meningkatkan kepuasan mahasiswa terhadap layanan proses pembelajaran pada Program Studi Teknik Informatika di Jurusan Teknik Informatika dan Komputer Politeknik Negeri Jakarta.

\section{TINJAUAN PUSTAKA}

\section{A. Metode Perancangan Sistem Informasi}

Sistem informasi dapat berupa gabungan dari beberapa elemen teknologi berbasis komputer yang saling berinteraksi dan bekerja sama berdasarkan suatu prosedur kerja yang telah ditetapkan. Pemrosesan dan pengolahan data menjadi suatu bentuk informasi yang digunakan dalam mendukung keputusan[1]. Perancangan Sistem informasi memiliki berbagai jenis metode yang dapat digunakan oleh pengembang. Metode pengembangan tradisional dikenal dengan nama waterfall[2]. Metode terbaru dalam pengembangan sistem informasi adalah metode Lean. Sebelum memulai perancangan terlebih dahulu dibuat pemodelan bisnis dan infrastruktur dari sistem yang akan dibuat. Pemodelan menggunakan metode Lean menggunakan pendekatan XBMC dan SMC[3].

Perancangan dengan menggunakan metode tersebut akan menghasilkan model bisnis dan infrastruktur. Model bisnis menggunakan pendekatan XBMC sedangkan infrastruktur menggunakan pendekatan SMC. Untuk menghasilkan model proses dan data serta antar muka sistem menggunakan methodology/ pendekatan pemodelan object [3]. 


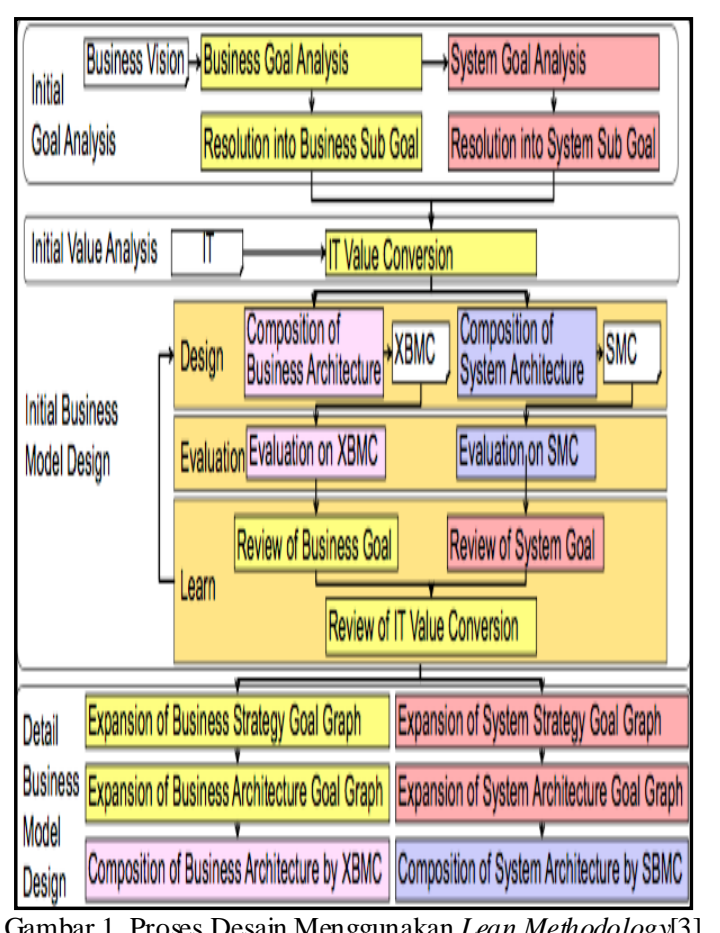

Gambar 1. Proses Desain Menggunakan Lean Methodology[3]

\section{B. Pemodelan dalam Analisis}

Pemodelan analis is dapat menggunakan dua pendekatan yaitu pendekatan terstruktur dan berorientasi objek[4]. Pendekatan berorientasi objek menggunakan UML. UML memiliki dua bagian model yaitu suplemental modelling, behavioral modelling, struktur modelling.

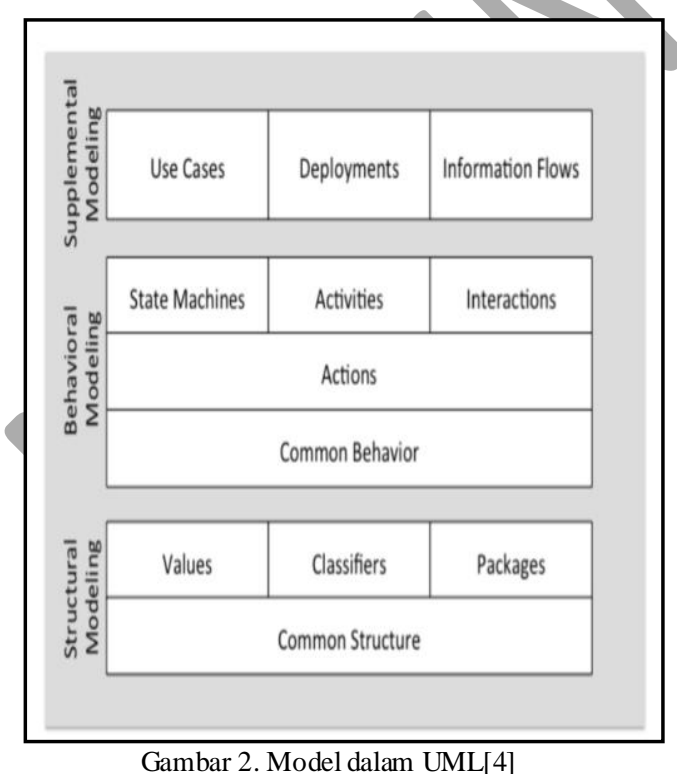

Gambar 2. Model dalam UML[4]

\section{A. Kerangka Teoritis}

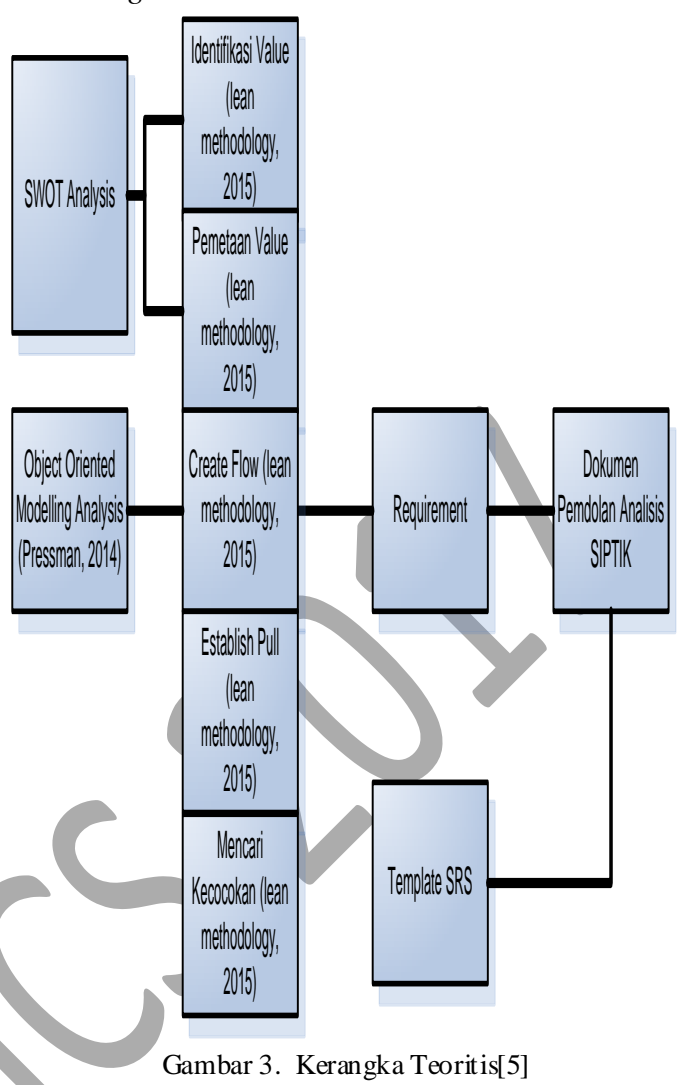

Pendekatan Lean memiliki lima tahapan yang berupa siklus[5]. Pada penelitian ini tahapan yang digunakan terdiri atas lima yaitu identifikasi value, pemetaan value, membuat alur, establish pull dan mencari kecocokan dari model alur yang telah dibuat. Dalam mengidentifikasi value dan melakukan pemetaan, digunakan model analisis menggunakan SWOT (Strenght, Weaknes, Opportunity dan Threat). Identifikasi value yang didapatkan akan dipetakan menjadi aplikasi-aplikasi yang dibutuhkan. Alur model diciptakan dengan menggunakan pendeakatan berorientasi objek.

\section{B. Alur Penelitian}




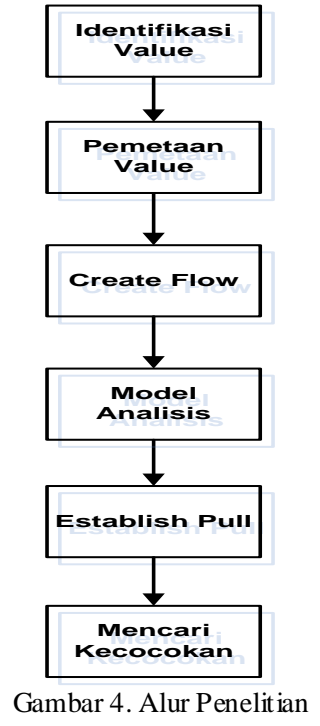

Perancangan sistem informasi pendidikan in i berada pada tahun ke 2 (dua) yaitu mengembangkan model sistem (gambar kerangka pikir penelitian). Sehingga penelitian tidak sampai dilakukan sebuah implemntasi sistem, hanya mencari model sistem yang sesuai dengan keinginan pengguna, dalam hal ini program studi Teknik Informatika pada Jurusan teknik Informatika dan Ko mputer, Politeknik Negeri Jakarta.

\section{IV.}

\section{HASIL DAN PEMBAHASAN}

\section{A. Identifikasi Value}

Analisis SWOT dilakukan pada komponenkomponen penting organisasi. Komponen penting organisasi menurut borang evaluasi diri perguruan tinggi adalah visi misi, tata pamong, mahasiswa, sumber daya manusia, kurikulum, sistem informasi, pembelajaran, penjaminan mutu dan mahasiswa. Dari semua komponen tersebut akan dipilih hasil analis is terkait layanan pembelajaran pada PNJ, baik yang berasal dari faktor internal (S-W) maupun factor eksternal (O-T). Analisis SWOT untuk komponen-komponen tersebut diuraikan melalui tabel-tabel analisis SWOT.

\section{B. Model Bisnis Aplikasi}

Pemodelan proses diawali dengan melakukan sebuah perancangan proses sistem melalui use case. Terdiri dari dua use case yaitu use case layanan pendidikan dan use case layanan skripsi.

Use case layanan pendidikan memiliki 4 (empat) aktor yaitu mahasiswa, dosen, KPS dan staf admin. Jika mahasiswa masuk ke dalam sistem, bisa melakukan aktivitas melihat data kurikulum sekaligus bisa men-download kurikulum, melihat data profil dosen serta dapat melihat data perangkat pembelajaran sekaligus bisa men-download perangkat pembelajaran. Aktivitas yang bisa dilakukan aktor "dosen" ke dalam sistem yaitu meng-input data profil dosen. Data dosen yang telah di-input ke dalam sistem akan di-approve oleh staf admin untuk melakukan validasi. Meng-upload data kurikulum dan meng-upload perangkat pembelajaran merupakan aktivitas aktor KPS ke dalam sistem.

Aktor mahasiswa melakukan aktivitas ke sistem seperti meng-input permintaan magang, melihat status permintaan, melihat jadwal sidang, mendaftar sidang, melihat pembimbing, mengaktivasi tempat magang kemudian akan diaktiviasi oleh panitia PKL kemudian akan muncul notifikasi pemberitahuan kepada mahasiswa, mendownload surat pengantar magang yang telah digenerate oleh KPS/Jurusan.

\section{Hasil}

Perancangan aplikasi sistem informasi pembelajaran TIK bersifat object oriented (berorientasi objek) dengan menggunakan Unified Modeling Language (UML) sebagai bahasa pemodelan yang semuanya tercatat lengkap dalam dokumen perancangan. Dan semua kebutuhan fungsional dan non-fungsional sistem tercatat dalam dalam dokumen software requirement specification (SRS).

Sehingga dapat disimpulkan bahwa kebutuhan perangkat lunak adalah sebagai berikut:

1. Menambahkan fitur pemeliharaan data dan aplikasi

2. Aplikasi memiliki kelebihan dalam mengotomatisasi pekerjaan-pekerjaan staf administrasi

3. Membuat aplikasi layanan terpadu pembelajaran sesuai kebutuhan organis asi

4. Membuat aplikasi berbasis web

5. Membuat sistem e-learning

Pada saat ini PNJ sedang mengembangkan sistem akademik dan e-learning. Sehingga sistem/ perangkat lunak tersebut tidak akan dibahas pada penelitian ini. Layanan pembelajaran yang ada pada jurusan TIK sesuai dengan observasi langsung. Layanan-layanan tesebut meliputi kegiatan PBM, kegiatan PKL, kegiatan Skripsi, Kegiatan Pe min jaman barang lab dan ko mpensasi.

\section{KESIMPULAN DAN SARAN}

\section{A. Kesimpulan}

Perancangan sistem informasi pembelajaran di Jurusan TIK dengan dihasilkannya desain perancangan data dan perancangan proses sistem yang terdapat dalam dokumentasi. Dokumen yang dihasilkan dari penelitian ini adalah dokumen 
analisis perancangan berupa dokumen software requirement specipication (SRS), sehingga apabila sistem ini diimplementasikan akan terjadi peningkatan kepuasan layanan Jurusan kepada mahasiswa.

Sistem informasi pembelajaran Jurusan TIK memiliki 2 fitur (aplikasi/modul) utama. Fitur-fitur tersebut adalah:

1. Fitur pembelajaran yang terdiri dari sub fitur atau sub sistem beranda yang berisi informasi, pengumuman dan jadwal perkuliahan, jumlah kompensasi mahasiswa berdasarkan absensi dan kehadiran mahasiswa di kelas, nilai yang diperoleh mahasiswa setiap mata kuliah yang di ambil. Semuanya tercatat dalam dokumen perancangan dan dokumen SRS.

2. Fitur layanan PKL yang terdiri dari sub fitur data perusahaan tempat magang, jadwal sidang, data pembimbing, pengajuan persetujuan magang, download surat pengantar magang. Semuanya tercatat dalam dokumen perancangan dan dokumen SRS.

\section{B. Saran}

Fitur yang ada sistem informasi pembelajaran di Jurusan TIK masih belum menampilkan seluruh proses bisnis yang ada di Jurusan, sehingga beberapa informasi masih belum bisa ditampilkan pada sistem informasi pembelajaran TIK. Fitur yang masih bisa ditambahkan pada sistem informasi TIK, seperti penjadwalan dan ruangan kelas. Pada fitur ini sistem bisa menampilkan informasi ruangan yang tidak terpakai, sehingga jika ada dosen yang ingin mengadakan kuliah penganti sudah tahu, ruangan dan jam berapa ruangan tersebut tidak terpakai.

Output yang dihasilkan dari setiap tahapan Lean methodology kurang tergambar dengan baik sehingga jika kita ingin menggunakan metodologi ini dibutuhkan gabungan dari beberapa metodologi lainnya.

\section{REFERENSI}

[1] Sinsuw, A., \& Najoan, X. (2013). Prototipe Aplikasi Sistem Informasi Akademik pada Perangkat Android. E-jornal Elektro dan Komputer , 1-10.

[2] Shelly, G. B., Cashman, T. J., \& Vermaat, M. E. (2008). Discovering Computers 4th Edition. Boston: Thomson.

[3] Ide, M., Amagai, Y., Aoyama, M., \& Kikushima, Y. (2015). A Lean Design Methology for Business Models and Its Application to IoT Business Model Development. Agile Conference (pp. -). -: IEEE.

[4] Pressman, Roger S. 2008.Software Engineering: A Pract itioner's Approach. s.l. : R.S. Pressman \& Associates, Inc., 2008.

[5] lean.org. (n.d.). lean. Retrieved maret 30, 2017, from lean.org: https://www.lean.org/What LLean/Principles.cfm

[6] CISA. (2016). Optimizing Soft ware Development With Lean Value Chain Analysis. ISACA Journal, 2, 1-3. 